\title{
Foreigners in the town. Experience of voluntary immigrants living in a small town
}

\author{
Daniel Markovic* and Anna Zilova \\ Catholic University in Ružomberok, Faculty of Education, Department of Social Work, Ružomberok, \\ Slovakia
}

\begin{abstract}
The aim of the paper is to unveil the experiences of voluntary immigrants to Slovakia related to their life in a small Slovak town and to identify opportunities for intervention through social work, particularly experience in the field of interpersonal relations, employment or during studies, and in the economic field. In research, we are interested in voluntary migrants who chose small towns in Slovakia, which are culturally and linguistically homogeneous. We have chosen a qualitative research strategy. Research design is grounded theory. As a research tool, we chose an individual structured interview (In-Depth Interview). For qualitative analysis of data, we used the coding; we set descriptive and inductive codes, subcategories and categories. The subject of research is eight voluntary immigrants to Slovakia who live in small towns for at least one year at the time of research. Thus, they meet the long-term migration criterion. Participants were selected on a deliberate basis to cover the phenomenon of voluntary migration. Due to the chosen research design, theoretical sampling is the case.
\end{abstract}

Key words: human migration, voluntary immigrants, social work.

\section{Introduction}

Human migration is the movement of people from one place to another with the intention of settling in a new location [1]. Asylum Seekers and Supplementary Protection Statistics show that Slovakia is rarely the target country of forcibly displaced people [2]. Emigration from Slovakia and its reasons are being examined relatively well [3, 4], but we see specific gaps in the research of voluntary immigration to Slovakia. Statistics after Slovakia joined the European Union (EU) show a significant, quadruple increase in the number of foreigners from both EU and non-EU countries living in Slovakia [5]. Migrants arriving in EU countries are usually trying to settle in large cities, where there are support nets made up of their natives and job opportunities in an international environment, which confirms the migration network theory. In research, we are interested in voluntary migrants who chose small towns in Slovakia, which are culturally and linguistically homogeneous. The aim of the paper is to find out the experiences of voluntary immigrants related to their life in a small Slovak town and to identify opportunities for intervention through social work. We were particularly interested in their experience in the field of interpersonal relations, in the employment or studies, and in the economic field.

\footnotetext{
* Corresponding author: daniel.markovic@ku.sk
}

(C) The Authors, published by EDP Sciences. This is an Open Access article distributed under the terms of the Creative Commons Attribution License 4.0 (http://creativecommons.org/licenses/by/4.0/). 


\section{Research design and methods}

We have chosen a qualitative research strategy. Research design is grounded theory. Since we have only carried out the first three steps of the grounded theory, the compilation of a new theory is not the content of this paper. As the research tool, we chose an individual structured interview (In-Depth Interview). For qualitative data analysis, we used the coding; we set descriptive and inductive codes, subcategories and categories. We have identified two research questions, looking for answers to them through 22 interview questions:

1. What is the life story of the participants before coming to Slovakia?

2. What are the participants' life experience in Slovakia in the field of interpersonal relations, own study or work, and in their economic situation?

As part of research, we used elements of biographical design. When interpreting the participants' answers to the question who is in your social network? we used the word cloud method to create an image consisting of words used to denote the terms, the size of each word denoting the frequency of the term in the participants' testimonials.

The subject of the research is voluntary migrants who moved to Slovakia and have been living in Slovakia at the time of research (July 2018) for at least one year or longer. There are eight participants; they were selected on a deliberate basis to cover the phenomenon of voluntary migration to Slovakia. Due to the chosen research design, the choice is in the form of theoretical sampling, a deliberate theoretical choice. In our research, it showed its typical features: changing the sample size during the research, selecting the participants with respect to the research goal and selecting special to borderline cases (differently developed countries, migration for study, work, and family reasons). All participants have experienced an immigration experience in Slovakia; they are competent to talk about the topic. Because of the research design, we can talk about them as informants. Participants come from European Union member states (Poland, United Kingdom), from other European country (Ukraine), from Asia (Turkmenistan), from North America (United States of America), from the Caribbean (Haiti). Participants belong to all four groups of countries grouped according to the HDI Human Development Index. The specificity of the informants, which was the intention of the researcher, is the education of the participants. Higher level of education develops the ability of abstract thinking, argumentation and generalization, so we expect skilled and relevant answers from participants. In the presentation of the research results, we do not give the names of the participants, their place of residence, the exact age (but the age group information), the employer or college. These data are known to the researcher but are not included in the research results as part of the anonymity and privacy of the participants.

\section{Results}

\subsection{Life stories of participants are captured}

In participants' profiles, their compact characteristics generated from answers to 18 interview questions are captured. We present shortened life stories (biographical design) of participants bound to their countries of origin for the period before coming to Slovakia.

The participant 1 belongs to the age group of 16-20 years, she is a woman, single, and her highest achieved education is secondary school - general education. She has been in Slovakia for two years; currently she is studying social work at the university. She is from Ukraine (HDI 0.743), has Ukrainian nationality. She worked there as a photographer and as a worker in Copy centre. She left Ukraine as a seventeen-year-old girl. She decided to change the country because of more information about her study field in Slovakia, comparing to Ukraine. She moved to Slovakia and not to other country because of security. Before moving 
to Slovakia, she looked up information from the Internet and "heard a lot from a teacher of the Slovak language". She studies here because, in her words, social work is more developed in Slovakia than in Ukraine. During her stay in Slovakia, she offers unpaid or volunteer work as a part of the study program. She often helps students from Ukraine because she knows how it feels to be alone in a foreign country.

The participant 2 belongs to the age group of 16-20 years. She is a woman and is single. Her highest achieved education is secondary school - in the field of fine arts. She is currently studying at the university in the second year and is studying at the Faculty of Fine Arts. She likes painting, likes to draw. She is from Ukraine (HDI 0.743), has Ukrainian nationality. She did not work in Ukraine before she left for Slovakia. The main reason for the change of country for P2 was "more options for the future" than in Ukraine. She moved to Slovakia and not to other country because of study opportunities in Slovakia. She helps her peers in Slovakia because "people need it".

The participant 3 is a woman who belongs to the age group of $31-40$ years. She is married. Her highest achieved education is third, doctoral degree. She studied the teaching of Slovak language and literature and Religious education, and later the Theory of Teaching of Religious Education. She has been living in Slovakia with a break from 1999, first for study, and since 2007 because of marriage. She works as an assistant in a facility focusing on education. She joined the workplace because she could not find other job near her home in 2009. Now she likes her work and she is doing it with pleasure. She is from Poland (HDI 0.855), her nationality is Slovak. After studies she returned to Poland, where she worked as a teacher. She started living in Slovakia for the second time because of marriage. She moved to Slovakia and not to other country because of the university and marriage. She gained information about Slovakia before coming to Slovakia at school and in her own family. She is financially supporting the charitable and volunteer area in Slovakia.

Participant 4 is a man; he belongs to the age group of $21-30$ years. He is single; his highest achieved education is baccalaureate. He studied Russian language and culture. He chose the study program because he likes the Russian language. He has been in Slovakia for 6 years. He works as a manager at the bar. He is from Turkmenistan (HDI 0.691) and has Turkmen nationality. In his country, he worked as a manager. He left Turkmenistan in 2012. The reason for the change of the country was university studies. The choice of Slovakia and no other country was the choice of his parents. He did not have much information about this country before he arrived in Slovakia, nor did he try to find them anywhere. He worked as a volunteer in Slovakia in organization Smile as a gift.

Participant 5 is a man; he belongs to the age group of 21-30 years. He is married; his highest achieved education will soon be a third, doctoral degree. He studied management and now is studying social work because his country currently needs many social workers due to its difficult situation. He has been living in Slovakia for 7 years. He is from Haiti (HDI 0.493), his nationality is Haitian. He studied in his own country and worked part-time as a "Help Manager". The main reason for moving to Slovakia was university studies. P5 chose Slovakia and no other country thanks to a Slovak friend, "with whom I met in my country and who invited me to study here in Slovakia." At the same time, this friend provided him with information on Slovakia before moving to the Slovak Republic. He helped other people in Slovakia many times, whenever they asked for it.

Participant 6 is a woman who belongs to the age group of 31-40 years. She is married. She has achieved third degree, a PhD in Theology and Biblical Sciences. She works as an assistant at a college because she can use her education and knowledge there. She has been living in Slovakia for 13 years, she is from Ukraine (HDI 0.743), is of Ukrainian nationality. Before coming to Slovakia, she did not work, but she studied. She left her native country 
when she was 19 years old. After leaving Ukraine she did not come to Slovakia straight away, she came "for her husband who returned to his native country after graduation abroad". She decided to move to Slovakia and not to other country because of job opportunities for her and her husband. Before the immigration, she looked up information about Slovakia in various sources: from interviews with a future husband, from newspapers, from acquaintances who were Slovaks. In Slovakia, she did not work as a volunteer because she was very busy and gradually gained family responsibilities.

Participant 7 is a man belonging to the age group of 31-40 years. He is married. He has received Bachelor's degree in Corporate Governance and Finance. He has been in Slovakia for three years. He is from the United States of America (HDI 0.920), nationality is stated as American. This is because Americans do not recognize their nationality by ethnicity but by citizenship. He was born in North Carolina, where he also graduated from college. He worked there as a regional manager of the Evangelization Association. He left for family reasons, his wife is originally from Slovakia, and she "owns and operates business in Slovakia". He decided for Slovakia and not for other country because "the wife is from Slovakia and business was in Slovakia". He jokes that he did not have a choice. He works as a private English teacher, owns and operates commercial property for rent. In Slovakia, he also does volunteer and unpaid work, especially for Christian communities and churches. He says his family has a heart for those who are not Christians, or who have been "hurt" by the church in the past.

Participant 8 is a man belonging to the age group of $31-40$ years. He is single. During his studies, he achieved the Bachelor's degree in graphic design. He has been in Slovakia for 3 and half years already. He is from the United Kingdom (HDI 0.909) and is of British nationality. In his country, he graduated from college, worked as a lifeguard. The main reason for moving to Slovakia was a different lifestyle. He decided for Slovakia and not for other country because of job opportunity. He gained information about Slovakia before his arrival from his partner. He works as a customer care agent in a facility focused on computers because he has good experience with this service himself. He does not work as a volunteer.

\subsection{Comparison of native country with Slovakia}

Since the informants have lived in Slovakia for at least one year, we were interested in their comparison of Slovakia with their country of origin in the field of human relations, in employment or study, and in the economic sphere.

When comparing, participants tended to think in the scale as better - worse, more less, so we offer the following breakdown of response groups based on subjective ratings of participants:

- In Slovakia, there are better: "You have less corruption than in Ukraine" (P1). "The economy is more stable in Slovakia. People are more positive and better" (than in Ukraine, author's note) (P1). "I think there are better opportunities in Slovakia, better teachers and more opportunities for travelling and studying. From the economic point of view, it is also better" (P2). "Slovakia is a more stable country than mine in finance as well as in government areas" (P4). "There are many options for young people more than in my country. There are many laws in Slovakia that are very good, unlike in my own country" (P5). "At work, I can deal with what I studied, I do not know if I would have the opportunity to have a similar position in the country I come from" (P6). "Economically, Slovakia is much more developed and more stable; even if I worked in a similar region and a similar workplace in the country I come from, I would not have a comparable social and economic standard" (P6). "Some of the biggest 
Table 1. Codes, subcategories and categories - Comparison of native country with Slovakia.

\begin{tabular}{|c|c|c|c|}
\hline Category & Subcategory & Inductive code & Descriptive code \\
\hline \multirow{24}{*}{$\begin{array}{l}\text { In Slovakia, } \\
\text { there are } \\
\text { better: }\end{array}$} & \multirow{15}{*}{$\begin{array}{l}\text { Economic, social } \\
\text { and communal } \\
\text { sphere }\end{array}$} & Less corruption is present & Less corruption \\
\hline & & Better economic situation & $\begin{array}{l}\text { Better conditions from the } \\
\text { economic point of view }\end{array}$ \\
\hline & & Cheaper accommodation & Lower living costs \\
\hline & & Cheaper healthcare & Lower healthcare costs \\
\hline & & $\begin{array}{l}\text { Lower costs related to } \\
\text { own children }\end{array}$ & Lower costs related to children \\
\hline & & \multirow{3}{*}{$\begin{array}{l}\text { More job and business } \\
\text { opportunities }\end{array}$} & Business opportunities \\
\hline & & & More job opportunities \\
\hline & & & Work application in the field \\
\hline & & \multirow{4}{*}{ More stability in Slovakia } & More stable economy \\
\hline & & & More stable financial sphere \\
\hline & & & More stable government \\
\hline & & & Slovakia is more stable \\
\hline & & $\begin{array}{l}\text { More developed country } \\
\text { (Slovakia) }\end{array}$ & Slovakia is more developed \\
\hline & & Better legislative & Better laws \\
\hline & & Better public transport & Good public transport \\
\hline & \multirow{4}{*}{$\begin{array}{l}\text { Personal } \\
\text { improvement in } \\
\text { Slovakia }\end{array}$} & \multirow{4}{*}{$\begin{array}{l}\text { Better and more } \\
\text { opportunities for people } \\
\text { in fields of study and } \\
\text { travel }\end{array}$} & Better opportunities \\
\hline & & & Better opportunities for young \\
\hline & & & Better study opportunities \\
\hline & & & Better travel opportunities \\
\hline & Environment & $\begin{array}{l}\text { Positively perceived } \\
\text { environment }\end{array}$ & Magnificent nature \\
\hline & \multirow{2}{*}{$\begin{array}{l}\text { People and } \\
\text { interpersonal } \\
\text { relations }\end{array}$} & $\begin{array}{l}\text { Positively perceived } \\
\text { personal characteristics }\end{array}$ & More positive and better people \\
\hline & & $\begin{array}{l}\text { Strong bonds between } \\
\text { family members }\end{array}$ & Strong bonds within family \\
\hline & \multirow[t]{2}{*}{ Lifestyle } & \multirow{2}{*}{$\begin{array}{l}\text { More active lifestyle } \\
\text { of Slovaks }\end{array}$} & $\begin{array}{l}\text { Slovaks are physically more } \\
\text { active }\end{array}$ \\
\hline & & & Healthier lifestyle of Slovaks \\
\hline \multirow{4}{*}{$\begin{array}{l}\text { In Slovakia } \\
\text { there are the } \\
\text { same: }\end{array}$} & \multirow[t]{3}{*}{$\begin{array}{l}\text { Social and } \\
\text { economic } \\
\text { situation }\end{array}$} & $\begin{array}{l}\text { Interpersonal relations in } \\
\text { Slovakia }\end{array}$ & Relations \\
\hline & & Work in Slovakia & Work \\
\hline & & $\begin{array}{l}\text { Economic situation in } \\
\text { Slovakia }\end{array}$ & Economic situation \\
\hline & Environment & Small area of the country & $\begin{array}{l}\text { Slovakia is also small (as Haiti, } \\
\text { author's note) }\end{array}$ \\
\hline \multirow{6}{*}{$\begin{array}{l}\text { In Slovakia, } \\
\text { there are } \\
\text { worse: }\end{array}$} & \multirow{5}{*}{$\begin{array}{l}\text { Economic and } \\
\text { social sphere }\end{array}$} & $\begin{array}{l}\text { Interpersonal relations are } \\
\text { limited to smaller social } \\
\text { circle of close relatives }\end{array}$ & Smaller circle of close relatives \\
\hline & & $\begin{array}{l}\text { Smaller emphasis on } \\
\text { customer service }\end{array}$ & $\begin{array}{l}\text { Smaller emphasis on customer } \\
\text { service }\end{array}$ \\
\hline & & Less of a comfort & $\begin{array}{l}\text { Less of a comfort in everyday } \\
\text { life }\end{array}$ \\
\hline & & Lower wages & Lower wages \\
\hline & & $\begin{array}{l}\text { Older, slower and less } \\
\text { modern healthcare } \\
\text { facilities }\end{array}$ & Worse healthcare facilities \\
\hline & Environment & $\begin{array}{l}\text { Weather (cold, because } \\
\text { the participant is from } \\
\text { warmer climate) }\end{array}$ & Weather \\
\hline
\end{tabular}


benefits: strong family relationships, low housing costs, business opportunities, health care costs, children's costs, spectacular nature and the surrounding area, good public transport" (P7). "Economically speaking, England is overpriced and unavailable for workers; more work is available in Slovakia. Slovaks complain less, are physically more active and care for a healthy lifestyle" (P8). "You do not have a war" (P1).

- In Slovakia, there are the same: "Relationships and work are the same" (P3). "Economic situation? Neither it is good in Slovakia, nor in Poland" (P3). "Slovakia is as small as my country" (P5).

- In Slovakia, there are worse: "In the area of interpersonal relations, I feel a certain limitation in Slovakia - the circle of the acquaintances is smaller" (P6). "Some of the most important negative: weather (originally from the hot climate), much lower wages, less emphasis on customer service, medical facilities are much older, slower and less modern, less comfort in everyday life" (P7).

P3 is aware of the limits of his opinion: "I feel like I have been here for too long, I cannot comment on it" (P3). Interestingly, P5 talks about his country of origin as of my country. Participants from countries with lower HDI positively assess the Slovak economy (and the rate of corruption), better and more positive people (and teachers), study and travel opportunities. They positively assess the stability of Slovakia, Slovak laws and possibilities of employment at work. Participants from countries with a higher HDI than Slovakia also commend business and business opportunities in Slovakia. The participant born in Poland perceives the work and relationships in Slovakia as the same and the economic situation as equally bad as it is in Poland. There are fewer negative statements about Slovakia than positive, participants view as the worst areas of human relations, salaries in the SR, and health care facilities. Participants coming from the warmer weather presented the weather in Slovakia as worse.

In this question, we were interested in the frequency of opinions on the stability changes in Slovakia. Participants perceive Slovakia as stable (more stable economy, more stable area of finance, more stable government, more stable Slovakia).

\subsection{Social network of voluntary migrants}

Young Immigrants, although coming to their family or friends, are getting into a new country, in a community where they start to make new contacts, new friendships and relationships. At the same time, they keep contacts with close people from the original country. That is why we were interested in who they are in touch with. When interpreting the participants' answers to the question who is in your social network? we used the word cloud. Most often, the friends and family were mentioned in the testimonies.

We have included the codes obtained from participants' testimonies into more general terms. For example, friends, fellows - to friends, partner, girlfriend and my boyfriend to a more general - partner. Interestingly, although there are four married participants, no one explicitly spoke of a spouse. It is possible that the spouse is hidden in the terms partner and family.

\subsection{The feelings of an immigrant in Slovakia}

Some of participants may be perceived as physically different for Slovaks, while with others, Slovaks may find out their foreign origin only during the communication (e.g. accent). With some participants, especially those who live longer in Slovakia, is difficult to notice some 


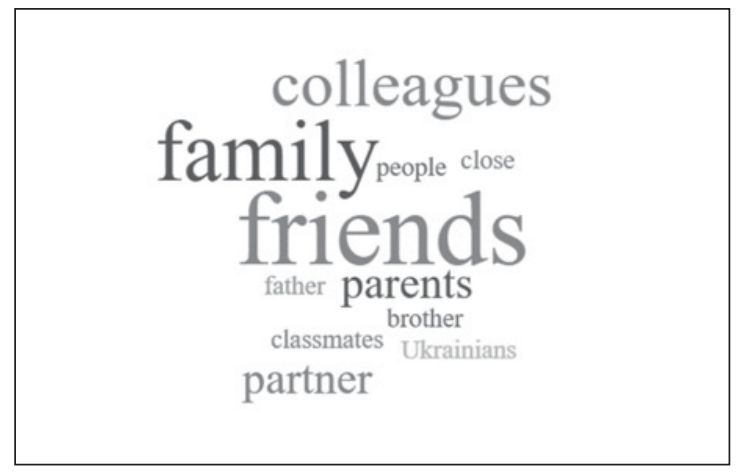

Picture 1. Social networks of participants. Source: own processing in the application WordItOut.

differences. The person living in the new country as an immigrant perceives different feelings. That is why we asked the participants how they feel in Slovakia as foreigners.

During interviews, the informants talked about both positive and negative feelings, so we divided their testimonies into the following groups:

- Positive feelings: "Sometimes I can forget that I am a stranger. I am comfortable in Slovakia"(P1). "Well, because I do not feel like a stranger, I feel like a Slovak" (P2). "I am at home (smile)" (P3). "I feel good, perhaps because of my perfect Slovak language, no one even knows I am a foreign person" (P4). "All right, I do not feel bound to be limited in some sphere of life because I am a stranger. It is the experience I have practically from the start of my stay" (P6).

- Neutral feelings: "Normal (P5)".

- Ambient feelings: "The difficult question, it depends on the situation. The main daily barriers are of a cultural nature. There are positive and negative aspects of being foreign in Slovakia" (P7).

- Negative feelings: "I feel like an outsider because I do not speak a language" (P8).

It is natural that the feelings of an immigrant, even if it is a voluntary migrant, are not only positive in the new country. Of course, they are variable, depending on many factors.

\subsection{Reactions of Slovaks on immigrants}

We asked the participants how the Slovaks responded to them being foreign.

As in the previous question, the responses ranged on the scale positively - negative.

- Positive: "They say I am already good at speaking Slovak" (P1). "They always try to help me" (P2). "Some responses are positive ..." (P5) "My English is sometimes attractive because people want to learn more effectively" (P7).

- Neutral: "They always ask me: Where are you from? How long do you travel home? Do you like it here?" (P1). "Nobody even knows I am a foreigner" (P4). "Neutrally, sometimes I awaken curiosity" (P6). "They are usually shy and surprised that I live here" (P8).

- Negative: "Sometimes I can hear:" Slovakia for the Slovaks!. "Foreigners have no rights but have duties. Even: "go home" "(P1). "During the study, they sometimes reacted negatively, but now it is OK, they no longer hear the accent" (P3). "... and at the same time many negative reactions that I do not care about because I know who I am, so for 
Table 2. Codes, subcategories and category - Reactions of Slovaks on Immigrants.

\begin{tabular}{|c|c|c|c|}
\hline Category & Subcategory & Inductive code & Descriptive code \\
\hline \multirow{13}{*}{$\begin{array}{l}\text { Reactions } \\
\text { of Slovaks to } \\
\text { foreigners: }\end{array}$} & \multirow{4}{*}{ Positive reactions } & $\begin{array}{l}\text { Positive reactions about } \\
\text { speaking Slovak language }\end{array}$ & $\begin{array}{l}\text { They say that I speak } \\
\text { good Slovak }\end{array}$ \\
\hline & & $\begin{array}{l}\text { Experience with } \\
\text { helpfulness of Slovaks }\end{array}$ & They always try to help \\
\hline & & $\begin{array}{l}\text { Positive reactions because } \\
\text { of attractive mother } \\
\text { language (English) }\end{array}$ & $\begin{array}{l}\text { Mostly positive } \\
\text { reactions because of } \\
\text { English }\end{array}$ \\
\hline & & $\begin{array}{l}\text { Non-specified positive } \\
\text { reactions }\end{array}$ & $\begin{array}{l}\text { Some of the reactions are } \\
\text { positive }\end{array}$ \\
\hline & \multirow{4}{*}{ Neutral reactions } & $\begin{array}{l}\text { Slovaks often react with } \\
\text { asking the same question: } \\
\text { where is she from, how } \\
\text { long does it take to travel } \\
\text { home, if he/she likes it } \\
\text { here. }\end{array}$ & $\begin{array}{l}\text { They ask repetitive, } \\
\text { stereotypical questions }\end{array}$ \\
\hline & & $\begin{array}{l}\text { Slovaks do not realize she } \\
\text { is a foreigner }\end{array}$ & $\begin{array}{l}\text { They do not know that I } \\
\text { am a foreigner }\end{array}$ \\
\hline & & $\begin{array}{l}\text { Arousing curiosity in } \\
\text { Slovaks }\end{array}$ & $\begin{array}{l}\text { Neutrally, I arouse } \\
\text { curiosity }\end{array}$ \\
\hline & & $\begin{array}{l}\text { Slovaks react surprised } \\
\text { and shyly }\end{array}$ & $\begin{array}{l}\text { They are shy and } \\
\text { surprised that I live here }\end{array}$ \\
\hline & \multirow{5}{*}{ Negative reactions } & $\begin{array}{l}\text { Xenophobic reactions } \\
\text { emphasizing, that } \\
\text { Slovakia belongs to } \\
\text { Slovaks }\end{array}$ & "Slovakia for Slovaks" \\
\hline & & $\begin{array}{l}\text { Xenophobic reactions } \\
\text { denying the rights of } \\
\text { foreigners and } \\
\text { emphasizing their duties }\end{array}$ & $\begin{array}{l}\text { "Foreigners do not have } \\
\text { rights, only duties" }\end{array}$ \\
\hline & & $\begin{array}{l}\text { In past negative reactions } \\
\text { because of accent }\end{array}$ & $\begin{array}{l}\text { They are no longer } \\
\text { negative, they do not } \\
\text { hear accent. }\end{array}$ \\
\hline & & $\begin{array}{l}\text { Many non-specified } \\
\text { negative reactions, is not } \\
\text { concerned with them }\end{array}$ & $\begin{array}{l}\text { Many negative reactions, } \\
\text { I do not care about them }\end{array}$ \\
\hline & & $\begin{array}{l}\text { Slovaks are avoiding him } \\
\text { because they do not speak } \\
\text { English well or do not } \\
\text { speak it at all }\end{array}$ & $\begin{array}{l}\text { They avoid me because } \\
\text { of English }\end{array}$ \\
\hline
\end{tabular}

me these negative reactions are nothing" (P5). "But there are many people who avoid me because they either do not speak English or are unsure communicating in English language" (P7).

Since the P1, P7 and P5 statements pointed to both positive and negative aspects, we divided them into two groups of testimonies. From the P5 response, we can also capture the strategy 
of dealing with negative response. A group of neutral responses is specific because one might argue that testimonies have a positive or negative undertone. From the interview, it was not possible to determine this sub-tone unambiguously, in contrast to clearly positive and clearly negative shades. In this question, we have captured the widest range of negative testimonies from all the questions.

\section{Discussion}

While staying in a small town, voluntary immigrants consciously or unknowingly integrate into the majority society; assimilation is also taking place. There are four models of migrant integration: Assimilative model of the migrant's integration, Segregate model of the migrant's integration, Multicultural model of the migrant's integration, and Model of the individual civic integration [6]. Our participants are more likely to remain in their home in Slovakia if an assimilation model of integration or a model of individual civic integration is present in their environment. Reardon describes seven areas of addressing social needs of migrants through social work: 1. Identifying and overcoming barriers, 2 . The need for culturally competent practice, 3. Circumstances of the arrival of clients in destination country, 4. Health concerns of the client, 5. Family dynamics, 6. Creating social connections, 7. The need for patience and respect [7]. Participants sometimes experience barriers in social contacts or even feelings of outsiders. From this area of social work solutions for migrants, we propose that social workers focus on creating social connections (such as prevention of solitude and isolation, pooling of clients with each other, community organizations and other entities) and identifying and overcoming barriers related to life in the country.

\section{Conclusion}

Voluntary immigrants identified these areas of positive experience of living in Slovakia: employment, economic and social conditions, leisure, cultural and development activities, environmental aspects. Participants perceive areas of human relations, wages and medical facilities as the worst. Participants have the advantage of quickly creating their new social network. Nevertheless, they sometimes experience barriers in social contacts or even feelings of outsiders. We propose that social workers focus on creating social connections (such as prevention of solitude and isolation, pooling of clients with each other, community organizations and other entities) and identifying and overcoming barriers related to life in the country.

\section{References}

[1] R. Perruchoud, J. Redpath-Cross (eds.) Glossary on Migration (IOM, Geneva, 2011)

[2] EUROSTAT, Asylum statistics (Accessed on 10/02/2019) Retrieved from https://ec.europa.eu/eurostat/statistics-explained/index.php/ Asylum_statistics\#Countries_of_destination:_Germany.2C_Italy_and_ France_the_main

[3] S. Vojtovich, The Impact of Emigration on Unemployment in Slovakia InzEkon 24(3), 207-216 (2013)

[4] A. Pavličková\& A. Dayanandan, Social networks and emigration in Slovakia, Migration and Development 4(2), 220-231 (2015), doi: 10.1080/21632324.2014.976942

[5] Štatistickýprehadlegálnej a nelegálnejmigrácie v Slovenskejrepublike, (Prezídium Policajnéhozboru, Bratislava, 2018) 
[6] IOM, Základnépojmy $\mathrm{v}$ oblastimigrácie a integráciecudzincov (Accessed on 10/02/2019). Retrieved from https://www.iom.sk/sk/pre-media/zakladnepojmy-o-migracii.html

[7] C. Reardon, Addressing the Social Work Needs of Older Immigrants and Refugees, Social Work Today (Accessed on 10/02/2019). Retrieved from http: //www. socialworktoday.com/news/enews_0911_01.shtml 